\title{
Growth of Okra Under Nitrogen Rates and Wastewater in the Brazilian Semiarid Region
}

\author{
Aldair de Souza Medeiros ${ }^{1}$, Sebastião de Oliveira Maia Júnior ${ }^{1}$, Giordano Bruno Medeiros Gonzaga ${ }^{1}$, \\ Thiago Cândido dos Santos ${ }^{1}$, Manoel Moisés Ferreira de Queiroz ${ }^{2}$, Renato Américo de Araújo Neto ${ }^{1}$, \\ Ivomberg Dourado Magalhães ${ }^{1}$, Rener Luciano de Souza Ferraz ${ }^{3}$, Patrícia da Silva Costa ${ }^{4}$, \\ Jailma Ribeiro de Andrade $^{1} \&$ Mariana de Oliveira Pereira ${ }^{4}$ \\ ${ }^{1}$ Center for Agrarian Sciences, Federal University of Alagoas, Rio Largo, Alagoas, Brazil \\ ${ }^{2}$ Science Center and Agri-food Technologies, Federal University of Campina Grande, Pombal, Paraíba, Brazil \\ ${ }^{3}$ Department of Agroecology and Agriculture, State University of Paraíba, Lagoa Seca, Paraíba, Brazil \\ ${ }^{4}$ Agricultural Engineering Academic Unit, Federal University of Campina Grande, Campina Grande, Paraíba, \\ Brazil \\ Correspondence: Rener Luciano de Souza Ferraz, Department of Agroecology and Agriculture, State University \\ of Paraíba, Lagoa Seca, Paraíba, Brazil. Tel: 55-083-3366-1297. E-mail: ferragroestat@gmail.com
}

Received: November 23, 2018

Accepted: January 19, 2019

Online Published: April 15, 2019

doi:10.5539/jas.v11n5p408

URL: https://doi.org/10.5539/jas.v11n5p408

\begin{abstract}
Water is one of the most important natural resources, especially for semiarid regions where it is very limited. Thus, some alternatives to preserve water are necessary. In this sense, we aimed to evaluate the effect of irrigation with post-treated domestic wastewater associated with different nitrogen rates on the growth of okra in the semiarid region of Brazil. The experiment was performed in the municipality of Pombal, state of Paraíba, Brazil. It was used a randomized block design with six nitrogen rates $\left(\mathrm{N}_{1}=0, \mathrm{~N}_{2}=40, \mathrm{~N}_{3}=80, \mathrm{~N}_{4}=120, \mathrm{~N}_{5}=\right.$ 160 , and $\mathrm{N}_{6}=200 \mathrm{~kg} \mathrm{ha}^{-1}$ ) and wastewater corresponding respectively to $0 ; 25 ; 50 ; 75 ; 100$; and $125 \%$ of the fertilization recommendation for the okra crop. In addition to these treatments, a control was added and the plants received $100 \%$ of the recommended dose of nitrogen and they were irrigated with water (IW). The control was compared with the treatments that were irrigated with wastewater and received the minimum $(0 \%)$ and the recommended $(100 \%)$ doses of nitrogen fertilization. The use of treated wastewater is an excellent technique for the reuse of water in semiarid regions, but it does not fully meet the okra nitrogen requirements.
\end{abstract}

Keywords: Abelmoschus esculentus L., nitrogen fertilization, water reuse

\section{Introduction}

Okra (Abelmoschus esculentus (L.) Moench) is a plant of African origin, belonging to the family Malvaceae, and rich in carbohydrates, proteins, vitamins, and minerals. Hence it is an excellent nutritional source for the human population (Galati, Cecílio Filho, Galati, \& Alves, 2013; Zubairu, Oladiram, Osunde, \& Ismaila, 2017). In addition, it is traditionally cultivated in the tropical regions, as it is considered a rustic plant, tolerant to high temperatures, and it does not require advanced technologies for its cultivation (Galati et al., 2013; Gunawardhana \& Silva, 2011). Therefore, the cultivation of this vegetable in semiarid regions becomes a potential source of income for the producers.

However, the crop is not tolerant to water scarcity. It requires a large amount of water during its cultivation (Gunawardhana \& Silva, 2011). This fact, together with the world population increase, leads to a greater demand for water and food. It requires more sustainable and innovative solutions to maintain natural resources, especially water, as it has become increasingly limited.Thus, as water scarcity affects several parts of the world and more frequently the regions of arid and semiarid climates, where it has significantly harmed agricultural crops, strategies that minimize this problem are of the utmost importance.

Of late, among the several strategies, the use of wastewater in the cultivation of different agricultural crops has been widely studied (Tak, Babalola, Huyser, \& Inam, 2013; Iqbal et al., 2015; Kummer, Grassi Filho, Lobo, \& Lima, 2017; Medeiros et al., 2017; Medeiros et al., 2018). This type of water, when adequately treated, becomes a viable alternative, as it allows the maintenance of agricultural production and the economics of surface water in 
regions with water scarcity, besides providing macro and micronutrients to the plants, mainly nitrogen (Pedrero, Kalavrouziotis, Alarcón, Koukoulakis, \& Asano, 2010; Iqbal et al., 2015; Medeiros, Nobre, Ferreira, Araújo, \& Queiroz, 2015).

The nitrogen is an essential element for the growth and development of cultivated plants. It plays an important role in the synthesis of chlorophylls, proteins, nucleic acids, hormones, and vitamins, as well as assisting in cell division and stretching (Firoz, 2009; Medeiros et al., 2018). In the okra crop, nitrogen rates vary from 60 to 180 $\mathrm{kg} \mathrm{ha}^{-1}$, depending on the fertility of soil in the region (Oliveira et al., 2014). However, nitrogen metabolism can be influenced by the quantity and quality of water used by plants. Therefore, futher research is needed on the use of nitrogen associated with wastewater for the growth of agricultural plants.

A technique that helps to obtain information on the growth and/or adaptation of plants in relation to the use of wastewater and nitrogen rates is the analysis of absolute and relative growth rates. This tool is widely used to investigate the effect of ecological phenomena, such as, the adaptability of species to diverse ecosystems, effects of fertilizers, and the influence of agronomic practices on growth (Benincasa, 2003). Thus, the objective of this study was to evaluate the effect of irrigation with post-treated domestic wastewater associated with different nitrogen rates on the growth of okra in a semiarid region of Brazil.

\section{Method}

The experiment was conducted at the Center of Agrifood Science and Technology (CCTA) of the Federal University of Campina Grande (UFCG), in Pombal-PB, Brazil. The climate of the region, according to the Köppen classification, is of the BSh type, representing a hot dry semiarid climate, with an average precipitation of $750 \mathrm{~mm}_{\text {year }}{ }^{-1}$ and an average annual evaporation of $2,000 \mathrm{~mm}$.

The treatments resulted in six nitrogen doses $\left(\mathrm{N}_{1}=0, \mathrm{~N}_{2}=40, \mathrm{~N}_{3}=80, \mathrm{~N}_{4}=120, \mathrm{~N}_{5}=160\right.$, and $\mathrm{N}_{6}=200 \mathrm{~kg}$ ha ${ }^{1}$ ) corresponding to $0 ; 25 ; 50 ; 75 ; 100$; and $125 \%$, respectively, of the recommendation of fertilization for the okra crop suggested by Oliveira et al. (2003) in association with wastewater (WW) for the irrigation of plants. In addition to these treatments, a control was added and the plants received $100 \%$ of the recommended dose of nitrogen and were irrigated with water (IW). The control was compared with treatments that were irrigated with wastewater and received the minimum $(0 \%)$ and the recommended $(100 \%)$ doses of nitrogen fertilization. The experimental design comprised of randomized blocks, with six treatments plus one, with four replications.

The Santa Cruz okra cultivar was used because it was very productive and the most planted in the region. Plastic lysimeters with $500 \mathrm{~L}$ capacity, filled with a layer of $15 \mathrm{~cm}$ of gravel, to facilitate draining of water, were used for the plants' conduction. Each lysimeter was completely filled with soil, classified as Entisols (Fluvents), sandy-loam, non-saline and non-sodic. The material came from the municipality of Pombal, Paraíba. The soil chemical and physical characteristics (Table 1) were determined according to the methodologies recommended by Embrapa (1997).

Table 1. Soil chemical and physical attributes used during the experiment

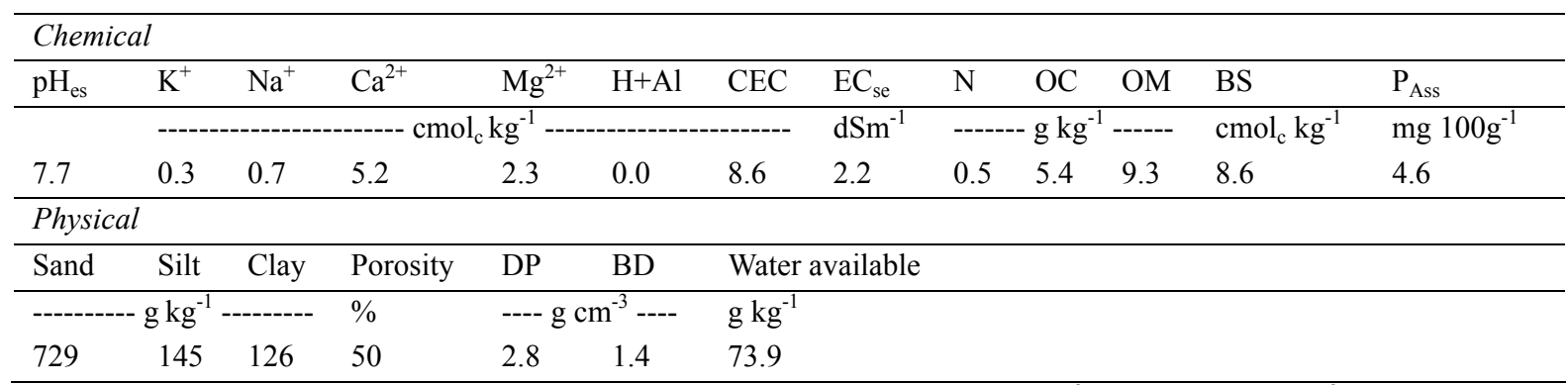

Note. $\mathrm{pH}_{\mathrm{se}}=\mathrm{pH}$ of saturation extract; $\mathrm{K}^{+}=$Potassium; $\mathrm{Na}^{+}=$Sodium; $\mathrm{Ca}^{2+}=$ Calcium; $\mathrm{Mg}^{2+}=\mathrm{Magnesium}$; $\mathrm{H}+\mathrm{Al}=$ Hydrogen + Aluminium $; \mathrm{CEC}=$ Cation Exchange Capacity; $\mathrm{EC}_{\mathrm{se}}=$ Eletric Conductivity in the saturation extract; $\mathrm{N}=$ Nitrogen; $\mathrm{OC}=$ Organic Carbon; $\mathrm{OM}=$ Organic Matter; BS = Bases Sum; Pass = Assimilable Phosphorus; DP = Density of Particles; BD = soil Bulk Density.

After conditioning in the lysimeters, the soil was placed near the field capacity, through the capillary saturation method, followed by free drainage, using irrigation water. The sowing was done directly in the lysimeters, with five seeds each. Twenty days after emergence (DAE), thinning was done, leaving both plants more vigorous. 
The nitrogen source used was urea $(45 \%$ of $\mathrm{N})$ and to reduce losses by volatilization and/or leaching, nitrogen fertilization was divided in three top-dressing applications for every ten DAE. The cultural treatments carried out during the crop cycle were phytosanitary control, mainly of aphids (Aphis gossypii) and scalpers (Dactylopius coccus), with applications of $100 \mathrm{~mL}$ of the systemic insecticide (concentration $1 \mathrm{~g} \mathrm{~L}^{-1}$ ) to the soil via irrigation water. Control of spontaneous plants from manual weeds inside the lysimeters was carried out weekly.

The wastewater used in the experiment came from showers, sinks, and urinals of the bathrooms located at the UFCG, Campus of Pombal, collected by pipes and deposited in a septic tank, which was connected by means of a tube inserted at the lower end to a plastic container, of $500 \mathrm{~L}$ capacity, functioning as an effluent distribution reservoir. This distribution occurred by piping up to three different intermittent aerobic filters (each filter receiving $50 \mathrm{~L}$ of wastewater every 6,8 , and 12 hours). The effluent produced was stored in a plastic container with a capacity of $500 \mathrm{~L}$. The filters were constructed by adapting plastic containers with a capacity of $250 \mathrm{~L}$ each. The lower part of the containers had a layer of $10 \mathrm{~cm}$ of gravel, followed by $50 \mathrm{~cm}$ of sand, and in the upper part another layer of $5 \mathrm{~cm}$ of gravel, to standardize the flow (Figure 1).

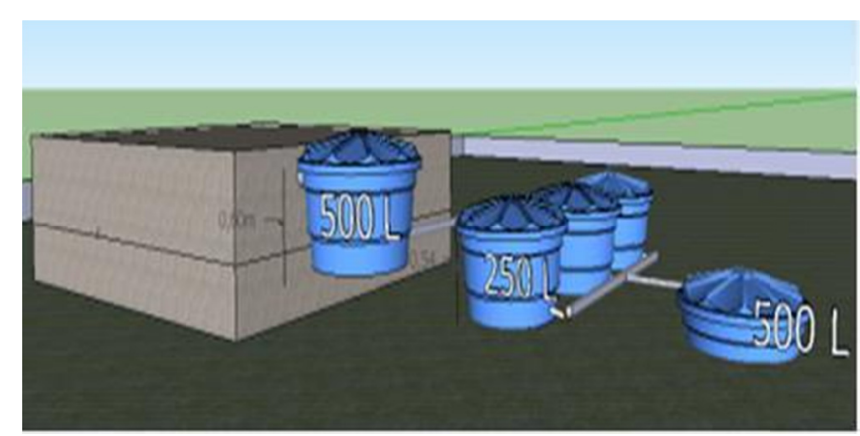

Figure 1. Wastewater treatment system with intermittent flow sand filters

Table 2 shows the mean values of the wastewater physical-chemical parameters before and after treatment with a sand filter, according to Sousa (2015). The results of the quality analysis of the WW after the use of the sand filter, is within the standards recommended by CONAMA (2005).

Table 2. Physical-chemical characteristics of the wastewater (WW) of the septic tank and after the sand filters

\begin{tabular}{|c|c|c|c|c|c|c|c|c|c|c|c|c|}
\hline \multicolumn{13}{|c|}{ Septic tank of wastewater } \\
\hline $\mathrm{pH}$ & $\mathrm{EC}_{\mathrm{a}}$ & DO & $\mathrm{Ca}$ & $\mathrm{Mg}$ & $\mathrm{Cl}^{-}$ & $\mathrm{P}$ & $\mathrm{N}$ & $\mathrm{Na}$ & K & COD & BOD & SAR \\
\hline & $\mathrm{dS} \mathrm{m}^{-1}$ & \multicolumn{10}{|c|}{ 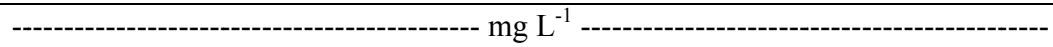 } & $\mathrm{mmol} \mathrm{L}^{-1}$ \\
\hline 8.3 & 0.82 & 0.4 & 34.4 & 25.4 & 102.5 & 0.8 & 0.01 & 0.02 & 0.09 & 89.8 & 15.6 & 3.6 \\
\hline \multicolumn{13}{|c|}{ Wastewater after the sand filters } \\
\hline $\mathrm{pH}$ & $\mathrm{EC}_{\mathrm{a}}$ & DO & $\mathrm{Ca}$ & $\mathrm{Mg}$ & $\mathrm{Cl}^{-}$ & $\mathrm{P}$ & $\mathrm{N}$ & $\mathrm{Na}$ & $\mathrm{K}$ & COD & BOD & SAR \\
\hline & $\mathrm{dS} \mathrm{m}^{-1}$ & \multicolumn{10}{|c|}{ - } & $\mathrm{mmol} \mathrm{L}{ }^{-1}$ \\
\hline 6.2 & 0.56 & 6.4 & 58.4 & 44.0 & 86.2 & 0.7 & 0.01 & 0.01 & 0.0 & 127.3 & 25.4 & 1.3 \\
\hline
\end{tabular}

Note. $\mathrm{pH}=$ Hydrogenionic potential; $\mathrm{EC}=$ Eletric Conductivity; $\mathrm{DO}=$ Dissolved Oxygen; $\mathrm{Ca}=\mathrm{Calcium} ; \mathrm{Mg}=$ Magnesium; $\mathrm{Cl}^{-}=$Chloride; $\mathrm{P}=$ Phosphorus; $\mathrm{N}=$ Nitrogen; $\mathrm{Na}=$ Sodium; $\mathrm{K}=$ Potassium; $\mathrm{COD}=$ Chemical Oxygen Demand; BOD = Biochemical Oxygen Demand; SAR = Sodium Adsorption Ratio

At 38, 58, and $78 \mathrm{DAE}$ the plant height $(\mathrm{PH}$, in $\mathrm{cm})$ was evaluated, measuring the distance between the plant collar and the base of the youngest leaf, using a measuring tape; the number of leaves (NL), considering only the leaves with complete development were counted; and the stem diameter (SD, in $\mathrm{mm}$ ) was determined $3 \mathrm{~cm}$ from the lap of the plants with the aid of a digital pachymeter; and leaf area $\left(\mathrm{LA}\right.$, in $\left.\mathrm{cm}^{2}\right)$ was obtained according to the methodology proposed by Severino, Cardoso, Vale, \&and Santos (2005), expressed by Equation (1):

$$
L A=0.84 \times(P+L)^{0.99}
$$

Where, A: leaf area in $\mathrm{cm}^{2}$; P: main nerve length in $\mathrm{cm}$; and L: leaf length in $\mathrm{cm}$. 
From then on, the absolute and relative growth rates of plant height and stem diameter were calculated, as also the relative growth rate of the leaf number and leaf area, both during the vegetative and reproductive stages, from the evaluations obtained between 38 and 58 DAE, and between 58 and 78 DAE, respectively.

The absolute (AGR) and relative (RGR) growth rates of plant height and stem diameter were obtained using the methodology presented by Benincasa (2003), expressed by Equation (2):

$$
\mathrm{AGR}=\frac{\mathrm{M} 2-\mathrm{M} 1}{\mathrm{~T} 2-\mathrm{T} 1}
$$

Where, AGR is absolute growth rate, M1 corresponds to the measure of the variable at time one (T1) and M2 the measure at the last evaluation time (T2), expressed by Equation (3):

$$
\mathrm{RGR}=\frac{\ln \mathrm{M} 2-\ln \mathrm{M} 1}{\mathrm{~T} 2-\mathrm{T} 1}
$$

Where, RGR corresponds to the relative growth rate, ln corresponds to the neperian logarithm of the measure of the variable (M1) in the first evaluation period (T1), and (M2) the measurement performed in the last evaluation period (T2).

The relative growth rates of leaf number and leaf area were obtained according to the methodology proposed by Wang et al. (2006), expressed by Equation (4):

$$
\mathrm{RGR}=\left[\frac{\mathrm{M} 2-\mathrm{M} 1}{\mathrm{M} 1}\right] \times 100
$$

Where, RGR corresponds to the relative growth rate, M1 and M2 correspond to the initial and final evaluations, respectively, of each phenological stage.

The data were submitted to analysis of variance by the $\mathrm{F}$ test $(p<0.05)$, and in the case of significance, regression analysis was performed for the nitrogen rate split. The Tukey test was performed to compare the means of the treatments that were irrigated with water that had a rate of $100 \%\left(160 \mathrm{~kg} \mathrm{ha}^{-1}\right)$ nitrogen according to the recommendation (control), with those that were irrigated with wastewater and received $0 \%\left(0 \mathrm{~kg} \mathrm{ha}^{-1}\right)$ and $100 \%\left(160 \mathrm{~kg} \mathrm{ha}^{-1}\right)$ of the nitrogen recommendation. For these statistical analyses, the SISVAR software was used (Ferreira, 2014).

\section{Results}

The association of wastewater and nitrogen rates affected the absolute growth of plant height and stem diameter, both at the vegetative and reproductive stage (Table 3). In the vegetative stage, AGR-PH increased linearly from $0.59 \mathrm{~cm} \mathrm{day}^{-1}$ with a lowest rate of nitrogen $\left(0 \mathrm{~kg} \mathrm{~N} \mathrm{ha}^{-1}\right)$ to $1.43 \mathrm{~cm} \mathrm{day}^{-1}$ at the highest rate $\left(200 \mathrm{~kg} \mathrm{~N} \mathrm{ha}^{-1}\right)$, representing an increase of $58 \%$ between the lowest and highest rates of this nutrient. Although, in the reproductive stage, AGR-PH reached a maximum of $2.29 \mathrm{~cm}^{-1 a y^{-1}}$, with an estimated rate of $144.3 \mathrm{~kg}$ nitrogen $\mathrm{ha}^{-1}$ (Figures 2A and 2B).

In relation to AGR-SD at the vegetative stage, it increased from 0.013 at the lowest rate of nitrogen to $0.053 \mathrm{~mm}$ day $^{-1}$ when the highest rate was applied. In the reproductive stage it increased from 0.014 to $0.026 \mathrm{~mm} \mathrm{day}^{-1}$. These increases of AGR-SD represented $75.4 \%$ and $45.6 \%$ in the vegetative and reproductive stages, respectively (Figures 2C and 2D). 

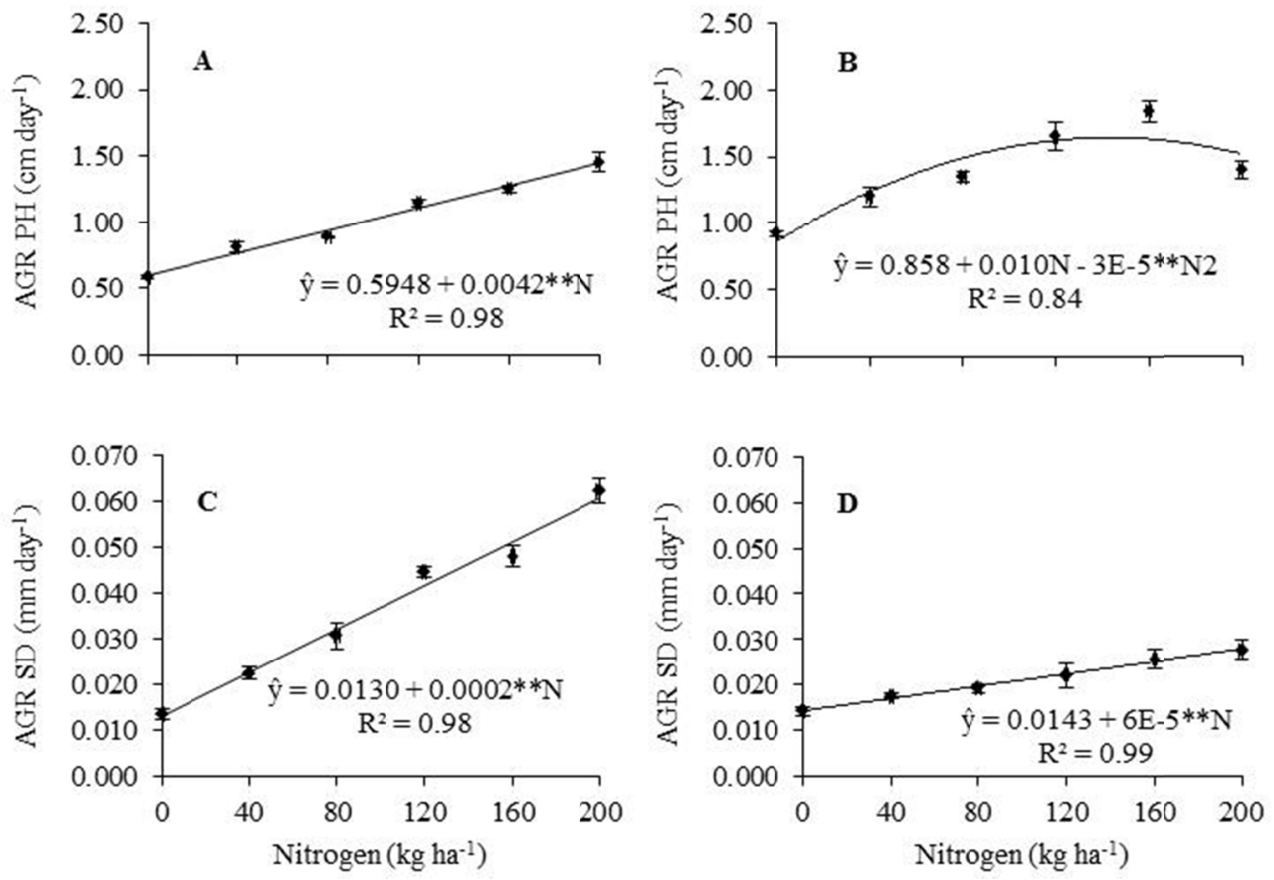

Figure 2. Absolute growth rates of plant height (AGR-PH) in the vegetative stage (A) and reproductive (B), and stem diameter (AGR-SD) in the vegetative stage $(C)$ and reproductive $(D)$ in okra under nitrogen doses and irrigation with wastewater

When comparing nitrogen treatments with and without wastewater, it was observed that nitrogen associated with wastewater $(\mathrm{N}+\mathrm{WW})$ favored absolute growth rates in relation to nitrogen with irrigation water $(\mathrm{N}+\mathrm{IW})$, except AGR-SD at the reproductive stage, since they were similar (Table 3).

Table 3. Summary of analysis of variance for absolute growth rates of plant height (AGR-PH) and stem diameter (AGR-SD) in the vegetative and reproductive stages of okra under irrigation with wastewater and nitrogen fertilization

\begin{tabular}{|c|c|c|c|c|c|}
\hline \multirow{3}{*}{ Source of variation } & \multirow{3}{*}{ DF } & \multicolumn{4}{|c|}{ Medium squares } \\
\hline & & \multicolumn{2}{|c|}{ AGR-PH } & \multicolumn{2}{|c|}{ AGR-SD } \\
\hline & & Vegetative stage & Reproductive stage & Vegetative stage & Reproductive stage \\
\hline Nitrogen $(\mathrm{N})$ & 5 & $0.4123 * *$ & $0.4251^{* *}$ & $0.0012 * *$ & $0.0001 * *$ \\
\hline Linear regression & 1 & $2.0352 * *$ & $1.2245^{* *}$ & $0.0063^{*}$ & $0.0005^{* *}$ \\
\hline Quadratic regression & 1 & $0.0000^{\mathrm{ns}}$ & $0.5616^{* *}$ & $0.0000^{\mathrm{ns}}$ & $0.0000^{\mathrm{ns}}$ \\
\hline Block & 3 & 0.0013 & 0.0042 & 0.0000 & 0.0000 \\
\hline Residue & 15 & & & & \\
\hline CV $(\%)$ & & 8.28 & 10.65 & 11.30 & 14.94 \\
\hline Treatments & & Averages & & & \\
\hline $\mathrm{N}_{1}\left(0 \mathrm{Kg} \mathrm{ha}^{-1}\right.$ of $\left.\mathrm{N}+\mathrm{WW}\right)$ & & $0.5787 \mathrm{c}$ & $0.9212 \mathrm{c}$ & $0.0135 \mathrm{c}$ & $0.0142 b$ \\
\hline $\mathrm{N}_{4}\left(160 \mathrm{~kg} \mathrm{ha}^{-1}\right.$ of $\left.\mathrm{N}+\mathrm{WW}\right)$ & & $1.2550 \mathrm{a}$ & $1.8437 \mathrm{a}$ & $0.0480 \mathrm{a}$ & $0.0257 \mathrm{a}$ \\
\hline Control (160 kg ha ${ }^{-1}$ of $\left.\mathrm{N}+\mathrm{IW}\right)$ & & $1.1100 \mathrm{~b}$ & $1.2762 \mathrm{~b}$ & $0.0367 \mathrm{~b}$ & $0.0242 \mathrm{a}$ \\
\hline
\end{tabular}

Note ${ }^{\text {ns }}=$ not significant, ${ }^{*}=$ significant at $5 \%$ probability level $(p<0.05), * *=$ significant at $1 \%$ probability level $(p<0.01)$ by F-test; DF = degrees of freedom; $\mathrm{CV}=$ coefficient of variation. Means followed by the same letter in the column do not differ by Tukey's test at $5 \%$ probability level $(p<0.05) . \mathrm{N}_{1}\left(0 \mathrm{~kg} \mathrm{ha}{ }^{-1}\right.$ of $\left.\mathrm{N}+\mathrm{WW}\right)=$ plants that received irrigation with wastewater and $0 \%$ of nitrogen recommendation; $\mathrm{N}_{4}\left(160 \mathrm{~kg} \mathrm{ha}^{-1}\right.$ of N+WW) $=$ plants that received irrigation with wastewater and $100 \%$ of nitrogen recommendation; control $\left(160 \mathrm{~kg} \mathrm{ha}^{-1}\right.$ of $\mathrm{N}+\mathrm{IW})=$ plants that received irrigation with water and $100 \%$ of the nitrogen rate recommended. 
All relative growth rates were influenced by nitrogen associated with wastewater treatments, except RGR-SD at the reproductive stage (Table 4). RGR-PH increased from 0.025 , at the lowest rate, to $0.045 \mathrm{~cm}^{-1} \mathrm{day}^{-1}$ at the highest nitrogen rate, at the vegetative stage, representing an increase of $44.4 \%$ between the lowest and highest nitrogen fertilizer rates. Although, in the reproductive stage, it reached a maximum of $0.032 \mathrm{~cm}^{-1}$ day $^{-1}$ with an estimated rate of $70 \mathrm{~kg} \mathrm{~N}^{-1}$ (Figures 3A and 3B). On the other hand, at the vegetative stage, RGR-SD increased from $0.010 \mathrm{~mm} \mathrm{~mm}^{-1}$ day $^{-1}$, at the lowest nitrogen rate, to $0.050 \mathrm{~mm} \mathrm{~mm}^{-1}$ day $^{-1}$ when the plants received the highest rate, representing an increase of $80 \%$ between the nitrogen rates. At the reproductive stage, RGR-SD had no influence on the treatments (Figures 3C and 3D).

Table 4. Summary of analysis of variance for relative growth rates of plant height (RGR-PH) and stem diameter (RGR-SD) in the vegetative and reproductive stages of okra under irrigation with wastewater and nitrogen fertilization

\begin{tabular}{|c|c|c|c|c|c|}
\hline \multirow{3}{*}{ Source of variation } & \multirow{3}{*}{ DF } & \multicolumn{4}{|c|}{ Medium squares } \\
\hline & & \multicolumn{2}{|c|}{ RGR-PH } & \multicolumn{2}{|c|}{ RGR-SD } \\
\hline & & Vegetative stage & Reproductive stage & Vegetative stage & Reproductive stage \\
\hline Nitrogen $(\mathrm{N})$ & 5 & $0.0004 * *$ & $0.0000 * *$ & $0.0009 * *$ & $0.0000 * *$ \\
\hline Linear regression & 1 & $0.0022 * *$ & $0.0000 * *$ & $0.0046^{* *}$ & $0,0000 * *$ \\
\hline Quadratic regression & 1 & $0.0000^{\mathrm{ns}}$ & $0.0001 * *$ & $0.0000^{\mathrm{ns}}$ & $0.0000^{\mathrm{ns}}$ \\
\hline Block & 3 & 0.0000 & 0.0000 & 0.0000 & 0.0000 \\
\hline Residue & 15 & & & & \\
\hline CV $(\%)$ & & 13.08 & 12.51 & 7.42 & 6.30 \\
\hline Treatments & & Averages & & & \\
\hline $\mathrm{N}_{1}\left(0 \mathrm{Kg} \mathrm{ha}^{-1}\right.$ of $\left.\mathrm{N}+\mathrm{WW}\right)$ & & $0.0245 \mathrm{c}$ & $0.0240 \mathrm{~b}$ & $0.0117 \mathrm{c}$ & $0.0097 \mathrm{a}$ \\
\hline $\mathrm{N}_{4}\left(160 \mathrm{~kg} \mathrm{ha}^{-1}\right.$ of $\left.\mathrm{N}+\mathrm{WW}\right)$ & & $0.0480 \mathrm{a}$ & $0.0322 \mathrm{a}$ & $0.0387 \mathrm{a}$ & $0.0127 \mathrm{a}$ \\
\hline Control $\left(160 \mathrm{~kg} \mathrm{ha}^{-1}\right.$ of $\mathrm{N}+\mathrm{IW}$ & & $0.0402 b$ & $0.0245 b$ & $0.0285 b$ & $0.0125 \mathrm{a}$ \\
\hline \multicolumn{6}{|c|}{$\begin{array}{l}\text { Note. }{ }^{\mathrm{ns}}=\text { not significant, } *=\text { significant at } 5 \% \text { probability level }(p<0.05), * *=\text { significant at } 1 \% \text { probability } \\
\text { level }(p<0.01) \text { by F-test; DF }=\text { degrees of freedom; CV = coefficient of variation. Means followed by the same } \\
\text { letter in the column do not differ by Tukey's test at } 5 \% \text { probability level }(p<0.05) . \mathrm{N}_{1}\left(0 \mathrm{~kg} \mathrm{ha}^{-1} \text { of } \mathrm{N}+\mathrm{WW}\right)= \\
\text { plants that received irrigation with wastewater and } 0 \% \text { of nitrogen recommendation; } \mathrm{N}_{4}\left(160 \mathrm{~kg} \mathrm{ha}^{-1} \text { of N+WW) }\right. \\
=\text { plants that received irrigation with wastewater and } 100 \% \text { of nitrogen recommendation; control }\left(160 \mathrm{~kg} \mathrm{ha}^{-1} \text { of }\right. \\
\mathrm{N}+\mathrm{IW})=\text { plants that received irrigation with water and } 100 \% \text { of the recommended nitrogen rate. }\end{array}$} \\
\hline
\end{tabular}



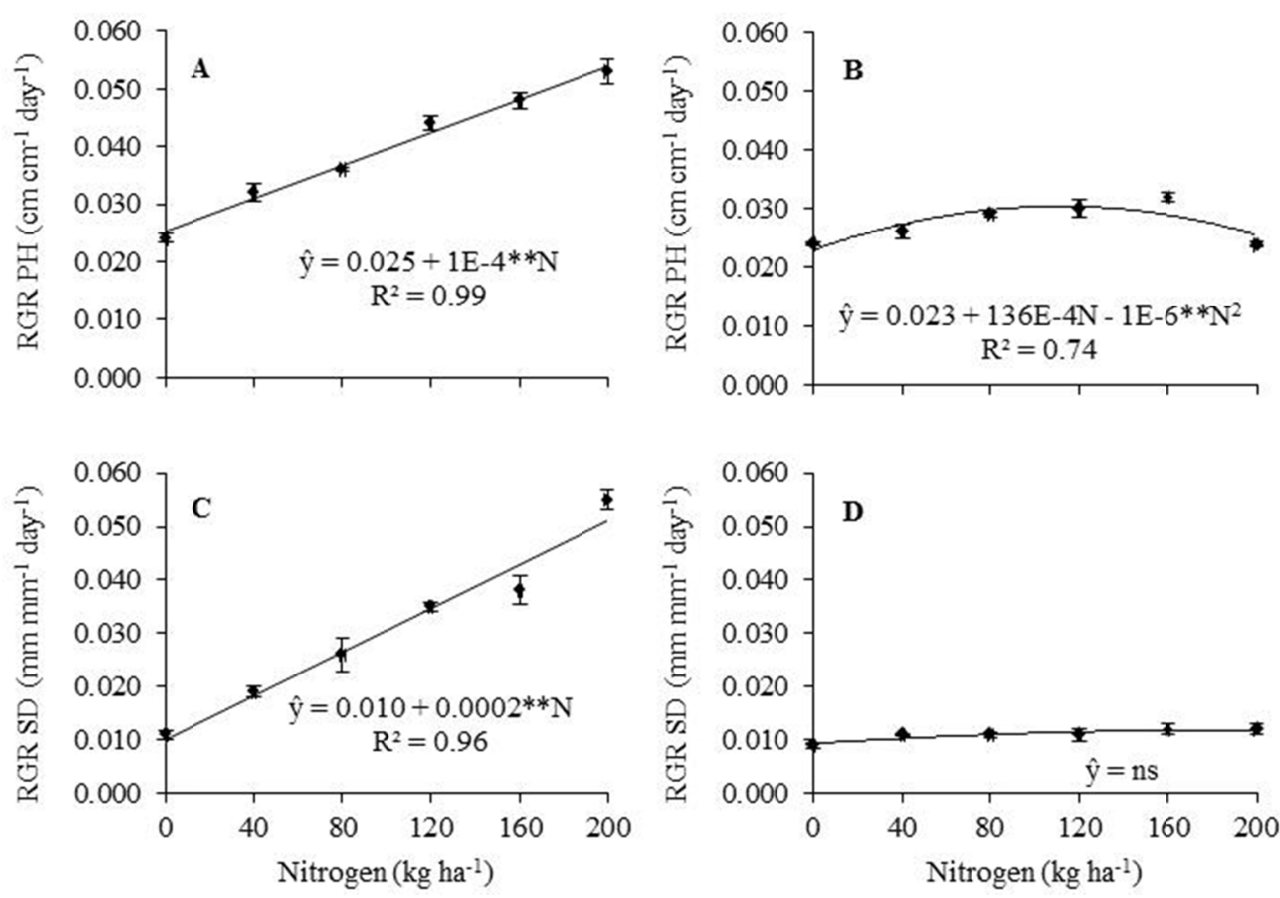

Figure 3. Relative growth rates of plant height (RGR-PH) in the vegetative stage (A) and reproductive (B), and stem diameter (RGR-SD) in the vegetative stage $(C)$ and reproductive $(D)$ in okra under nitrogen rates and irrigation with wastewater

As for nitrogen treatments with and without wastewater, it was observed that nitrogen associated with wastewater favored the relative growth rates of plant height and stem diameter in all stages except RGR-SD in the reproductive period (Table 5).

Table 5. Summary of analysis of variance for the relative growth rate (RGR) of leaf number (RGR-LN) and leaf area (RGR-LA) in the vegetative and reproductive stages of okra under irrigation with wastewater and nitrogen fertilization

\begin{tabular}{|c|c|c|c|c|c|}
\hline \multirow{3}{*}{ Source of variation } & \multirow{3}{*}{ DF } & \multicolumn{4}{|c|}{ Medium squares } \\
\hline & & \multicolumn{2}{|c|}{ RGR-LN } & \multicolumn{2}{|c|}{ RGR-LA } \\
\hline & & Vegetative stage & Reproductive stage & Vegetative stage & Reproductive stage \\
\hline Nitrogen $(\mathrm{N})$ & 5 & $16154.56^{* *}$ & $587.04 * *$ & $14444.97 * *$ & $2190.96^{* *}$ \\
\hline Linear regression & 1 & $78691.55^{* *}$ & $1982.23 * *$ & $68109.60^{* *}$ & $10394.41 * *$ \\
\hline Quadratic regression & 1 & $100.76^{\mathrm{ns}}$ & $741.07 * *$ & $2970.24 * *$ & $448.04 * *$ \\
\hline Block & 3 & 893.55 & 17.37 & 50.15 & 16.67 \\
\hline Residue & 15 & & & & \\
\hline $\mathrm{CV}(\%)$ & & 19.87 & 15.82 & 8.95 & 8.72 \\
\hline Treatments & & & & & \\
\hline $\mathrm{N}_{1}\left(0 \mathrm{Kg} \mathrm{ha}^{-1}\right.$ of $\left.\mathrm{N}+\mathrm{WW}\right)$ & & $22.0 \mathrm{~b}$ & $16.0 \mathrm{~b}$ & $84.7 \mathrm{c}$ & $20.7 \mathrm{~b}$ \\
\hline $\mathrm{N}_{4}\left(160 \mathrm{~kg} \mathrm{ha}^{-1}\right.$ of $\left.\mathrm{N}+\mathrm{WW}\right)$ & & $140.0 \mathrm{a}$ & $49.0 \mathrm{a}$ & $183.5 \mathrm{a}$ & $65.0 \mathrm{a}$ \\
\hline Control $\left(160 \mathrm{~kg} \mathrm{ha}^{-1}\right.$ of $\mathrm{N}+\mathrm{IW}$ & & $72.0 \mathrm{~b}$ & $40.5 \mathrm{a}$ & $154.7 \mathrm{~b}$ & $63.0 \mathrm{a}$ \\
\hline \multicolumn{6}{|c|}{$\begin{array}{l}\text { Note. }{ }^{\text {ns }}=\text { not significant; } *=\text { significant at } 5 \% \text { probability level }(p<0.05) ; * *=\text { significant at } 1 \% \text { probability } \\
\text { level }(p<0.01) \text { by F-test; DF = degrees of freedom; CV = coefficient of variation. Means followed by the same } \\
\text { letter in the column do not differ by Tukey's test at } 5 \% \text { probability level }(p<0.05) . \mathrm{N}_{1}:\left(0 \mathrm{~kg} \mathrm{ha}^{-1} \text { of N+WW) }\right. \\
\text { plants that received irrigation with wastewater and } 0 \% \text { of nitrogen recommendation; } \mathrm{N}_{4}:\left(160 \mathrm{~kg} \mathrm{ha}^{-1} \text { of N+WW) }\right. \\
=\text { plants that received irrigation with wastewater and } 100 \% \text { of nitrogen recommendation; control }\left(160 \mathrm{~kg} \mathrm{ha} \mathrm{kf}^{-1} \text { of }\right. \\
\mathrm{N}+\mathrm{IW})=\text { plants that received irrigation with water and } 100 \% \text { of the recommended nitrogen rate. }\end{array}$} \\
\hline
\end{tabular}


The relative growth rate of leaf number (RGR-LN) in the vegetative stage increased linearly from $22.3 \%$, with the lowest nitrogen rate, to $187.5 \%$ with the highest rate, whereas, at the reproductive stage, it reached a

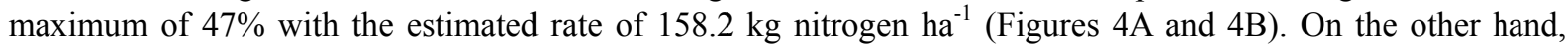
RGR-LA increased linearly at both stages of growth, and at the vegetative stage increased from $74.6 \%$ at the lowest rate to $227.9 \%$ at the highest nitrogen rate, and at the reproductive stage increased from $16.6 \%$ to $78.1 \%$ from the lowest to the highest rates of this nutrient, respectively (Figures $4 \mathrm{C}$ and $4 \mathrm{D}$ ).

In relation to nitrogen treatments with and without wastewater, it was observed that nitrogen associated with wastewater contributed to increase the relative growth rates of the leaf number and leaf area only in the vegetative stage when compared to nitrogen with irrigation water (Table 5).
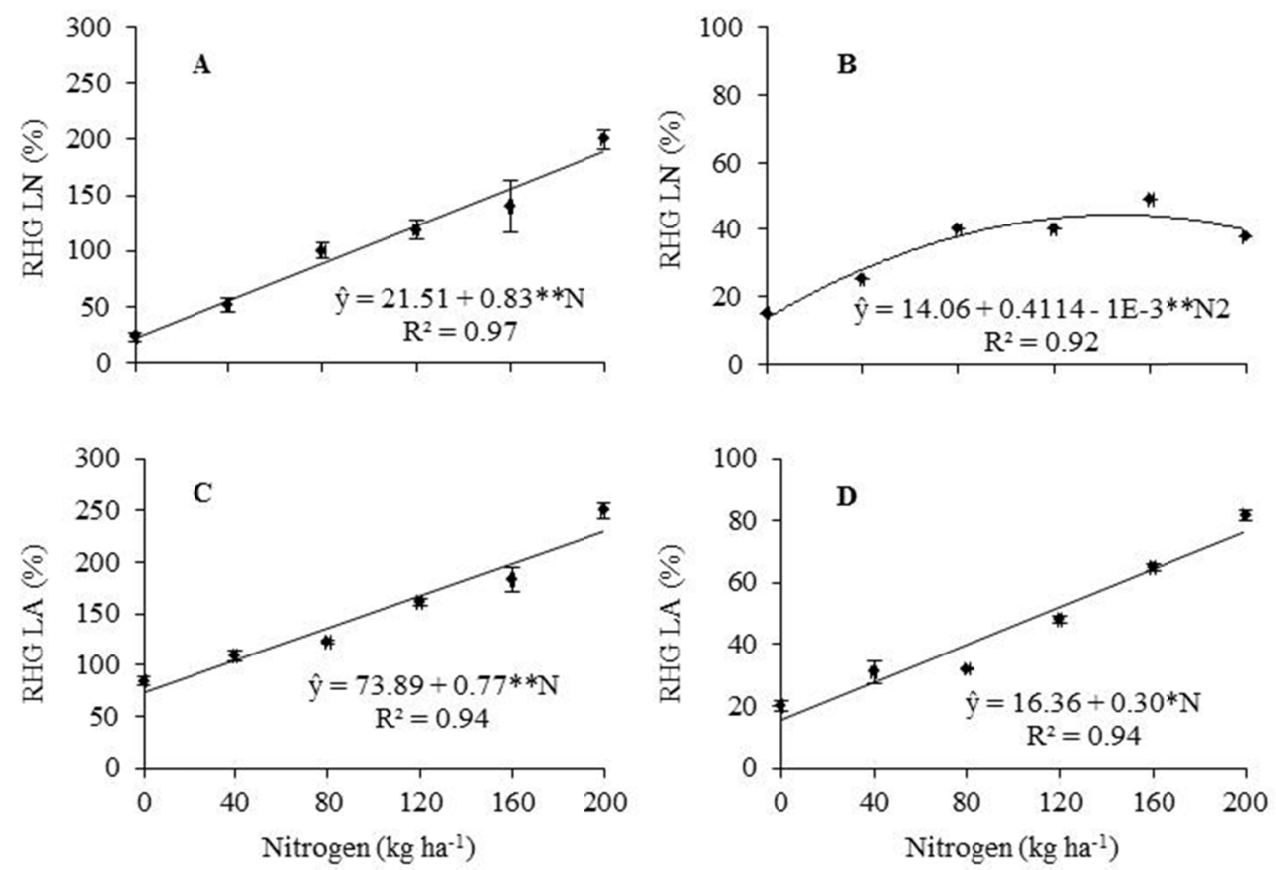

Figure 4. Relative growth rates of leaf number (RGR-LN) in the vegetative stage (A) and reproductive (B), and leaf area (RGR-LA) in the vegetative stage (C) and reproductive (D) in okra under nitrogen doses and irrigation with wastewater

\section{Discussion}

Our results show the importance of nitrogen during the growth of okra plants, as observed in other studies involving nitrogen fertilization in both okra (Firoz, 2009; Parmar, Bhanvadia, Chaudhary, \& Patel, 2016; Medeiros et al., 2018) and in other crops (Iqbal et al., 2015; Medeiros et al., 2015, 2017; Souza et al., 2017). The linear increase in absolute and relative growth of plant height and stem diameter, as well as the relative number and leaf area as a function of nitrogen supply, shows that the nutrient supply contributed to a higher growth of okra plants, especially in the vegetative stage, with rates varying between 0.59 and $2.29 \mathrm{~cm} \mathrm{day}^{-1}$. Perhaps, the increase of nitrogen rates favored cell division, and therefore, the increase of vegetative tissues, as indicated by Firoz (2009). Similar results were observed with eggplant (Medeiros et al., 2015, 2017; Souza et al., 2017) and chilli (Iqbal et al., 2015).

In contrast, plant height absolute and relative growth rate and relative number of leaves that decreased with the highest rates of nitrogen at the reproductive stage, show those high rates of nitrogen are not fully utilized for the stem and leaf growth in the respective period. This fact occurs due to the phenological stage of the plants, in which this nutrient was already being metabolized in the formation and growth of the fruits, thus, it had less contribution to plant growth and leaf formation. In the reproductive period of okra, the accumulation of nitrogen in the leaves stabilizes, even as it grows in the fruits due to being the main drain of the plant at that time (Galati et al., 2013), as verified by Parmar et al. (2016), when they observed that the increasing rates of nitrogen in the okra favored the number and size of fruits per plant. On the other hand, the plant may no longer be assimilating the nitrogen in the same proportion as at the beginning of the cycle. In this sense, Akintomide and Osundare 
(2015) evaluating the application of NPK in okra, at three, six, and nine weeks after planting, observed that the application at nine weeks after cultivation resulted in greater residual effects of $\mathrm{N}, \mathrm{P}$, and $\mathrm{K}$. This accumulation of nutrients was due to the period, as the okra plants did not have enough time to assimilate them and use them before the end of the cycle.

In the reproductive stage, the relative growth of the number of leaves indicates that the highest nitrogen rates was not used for the appearance of new leaves, due to the beginning of the senescence of the older leaves, till the stage of cultivation. Besides, there was a greater demand for fruit production (Galati et al., 2013; Parmar et al., 2016). However, the relative growth of the leaf area increased linearly as a function of the increasing rates of nitrogen, in the two phenological stages, evidencing that the adequate supply of nitrogen maintains the leaf expansion until the end of the okra cycle.

This condition indicates that nitrogen contributed to the leaf area expansion throughout the crop cycle, favoring light absorption and photosynthesis, and consequently, the production of photoassimilates. However, the nitrogen deficiency affects the enzymatic complex of plants, especially Rubisco, the enzyme responsible for carbon assimilation in C3 plants, whereas, this element is essential for protein synthesis (Carneiro et al., 2015). Similar to the growth of the leaf area, the absolute growth of stem diameter benefited from the increase of nitrogen rates, confirming the importance of nitrogen in the secondary structuring of okra plants, for better conformation and production support (Parmar et al., 2016).

In relation to the association of nitrogen with wastewater, we observed that the dose of $160 \mathrm{~kg}$ was higher than $160 \mathrm{~kg}$ of nitrogen with irrigation water for the growth of okra plants, especially in the vegetative stage. In the present study, the use of wastewater was associated with nutrient supply, especially nitrogen (Al-Jaboobi et al., 2014; Gatta et al., 2015; Medeiros et al., 2017, 2018), as all growth rates were higher in nitrogen associated with wastewater than in nitrogen with irrigation water, at the vegetative stage. Similar results were observed with pepper, since the use of wastewater together with nitrogen favored the growth of the plants in height, number of leaves, and leaf area (Iqbal et al., 2015). In addition to its direct effect, wastewater favored plants by releasing other nutrients such as, Mg, P, and K and increased the soil organic matter (Al-Jaboobi et al., 2014; Gatta et al., 2015; Medeiros et al., 2015).

We observed in the reproductive stage that only plant height was favored by the use of wastewater, which may be due to the lower growth in plant height at this stage, therefore, a lower nitrogen requirement (Medeiros et al., 2015, 2018), when compared to the other present nutrients (Gatta et al., 2015). However, the nutrients are harnessed for the maintenance and expansion of leaf and fruit formation.

The use of wastewater showed that it is a good strategy for the management of natural resources. It could replace the superficial water used for irrigation in semiarid regions, as well as reduce the use of synthetic nutrients, not only nitrogen. This can be investigated in a research evaluating the association of this type of water with other nutrients.

\section{Conclusion}

The association of wastewater and nitrogen favors the growth rates of okra plants during the vegetative stage. Therefore, the use of treated wastewater is an excellent technique for the reuse of water in semiarid regions, but it does not fully meet the okra nutritional requirements of nitrogen.

\section{References}

Akintomide, T. A., \& Osundare, B. (2015). Growth and yield responses of okra (Abelmoschus esculentus) and soil fertility status to NPK fertilizer application regimes. International Journal of Research Studies in Agricultural Sciences, 1(3), 11-16.

Al-Jaboobi, M., Tijane, M., El-Ariqi, S., El-Housni, A., Zouahri, A., \& Bouksaim, M. (2014). Assessment of the impact of wastewater use on soil properties. Journal of Materials and Environmental Science, 5(3), 747-752.

Benincasa, M. M. P. (2003). Análise de crescimento de plantas. Jaboticabal, SP: FUNEP.

Carneiro, M. M. L. C., Gomes, M. P., Santos, H. R. B., Reis, M. V., Mendonça, A. M. C., \& Oliveira, L. E. M. (2015). Fotorrespiração e metabolismo antioxidante em plantas jovens de seringueira cultivadas sob diferentes fontes de nitrogênio $\left(\mathrm{NO}_{3}^{-} \mathrm{e} \mathrm{NH}_{4}^{+}\right)$. Revista Brasileira de Ciências Agrárias, 10(1), 66-73. https://doi.org/10.5039/agraria.v10i1a4941 
CONAMA (Conselho Nacionaldo Meio Ambiente). (2005). Resolução no 357 de 17 de março de 2005 (p. 23 ). Diário Oficial da República Federativa do Brasil, Brasília, Brazil. Retrieved on March 29, 2018 from http://www.mma.gov.br/port/conama/legiabre.cfm?codlegi=459

EMBRAPA (Empresa Brasileirade Pesquisa Agropecuária). (1997). Manual de métodos de análise de solo (p. 212). Centro Nacional de Pesquisa de Solos, Rio de Janeiro, Brazil.

Ferreira, D. F. (2014). SISVAR: A guide for its bootstrap procedures in multiple comparisons. Ciência e Agrotecnologia, 38(2), 109-112. https://doi.org/10.1590/S1413-70542014000200001

Firoz, Z. A. (2009). Impact of nitrogen and phosphorus on the growth and yield of okra (Abelmoschus esculentus (L.) Moench) in hill slope condition. Bangladesh Journal of Agriculture Research, 34(4), 713-722. https://doi.org/10.3329/bjar.v34i4.5846

Galati, V. C., Cecílio Filho, A. B., Galati, V. C., \& Alves, A. S. (2013). Growth and accumulation of nutrients of the okra crops. Semina: Ciências Agrárias, 34(1), 191-200. https://doi.org/10.5433/1679-0359. 2013v34n1p191

Gatta, G., Libutti, A., Gagliardi, A., Beneduce, L., Brusetti, L., Borruso, L., Disciglio, G., \& Tarantino, E. (2015). Treated agro-industrial wastewater irrigation of tomato crop: Effects on qualitative/quantitative characteristics of production and microbiological properties of the soil. Agricultural Water Management, 149, 33-43. https://doi.org/10.1016/j.agwat.2014.10.016

Gunawardhana, M. D. M., \& Silva. C. S. (2011). Impact of temperature and water stress on growth yield and related biochemical parameters of okra. Tropical Agricultural Research, 23(1), 77-83. https://doi.org/ 10.4038/tar.v23i1.4634

Iqbal, S., Tak, H. I., Inam, A., Inam, A., Sahay, S., \& Chalkoo, S. (2015). Comparative effect of wastewater and groundwater irrigation along with nitrogenous fertilizer on growth, photosynthesis and productivity of chilli (Capsicum annuum L.). Journal of Plant Nutrition, 38, 1006-1021. https://doi.org/10.1080/01904167.2014. 991032

Kummer, A. C. B., Grassi Filho, H., Lobo, T. F., \& Lima, R. A. S. (2017). Fertilizante orgânico composto e água residuária no desenvolvimento de trigo irrigado por gotejamento. Irriga, 22(2), 275-287. https://doi.org/ 10.15809/irriga.2017v22n2p275-287

Medeiros, A. S., Nobre, R. G., Campos, A. C., Queiroz, M. M. F., Magalhães, I. D., \& Ferraz, R. L. S. (2017). Características biométricas e acúmulo de fitomassa da berinjeleira sob irrigação com água residuária e doses de nitrogênio e fósforo. Revista Brasileira de Agricultura Irrigada, 11(7), 1975-1985. https://doi.org/ 10.7127/rbai.v11n700665

Medeiros, A. S., Nobre, R. G., Ferreira, E. S., Araújo, W. L., \& Queiroz, M. M. F. (2015). Crescimento inicial da berinjeleira sob adubação nitrogenada e fosfatada e irrigada com água de reuso. Revista Verde de Agroecologia e Desenvolvimento Sustentável, 10(3), 34-40. https://doi.org/10.18378/rvads.v10i3.3656

Medeiros, A. S., Queiroz, M. M. F., Araújo Neto, R. A., Costa, P. S., Campos, A. C., Ferraz, R. L. S., ... Gonzaga, G. B. M. (2018). Yield of the okra submitted to nitrogen rates and wastewater in Northeast Brazilian semiarid region. Journal of Agricultural Science, 10(4), 409-416. https://doi.org/10.5539/jas.v10n4p409

Oliveira, A. P., Alves, A. U., Dornelas, C. S. M., Silva, J. A., Pôrto, M. L., \& Alves, A. U. (2003). Rendimento de quiabo em função de doses de nitrogênio. Acta Scientiarum Agronomy, 25(2), 265-268. https://doi.org/ 10.4025/actasciagron.v25i2.1761

Oliveira, A. P., Silva, O. P. R., Silva, J. A., Silva, D. F., Ferreira, D. T. A., \& Pinheiro, S. M. G. (2014). Produtividade do quiabeiro adubado com esterco bovino e NPK. Revista Brasileira de Engenharia Agrícola e Ambiental, 18(10), 989-993. https://doi.org/10.1590/1807-1929/agriambi.v18n10p989-993

Parmar, P. N., Bhanvadia, A. S., Chaudhary, M. M. \& Patel, A. P. (2016). Effect of spacing and levels of nitrogen on growth and seed yield of okra (Abelmoschus esculentus L. Moench) during kharif season. Journal of Pure and Applied Microbiology, 10(1), 485-488.

Pedrero, F., Kalavrouziotis, I., Alarcón, J. J., Koukoulakis, P., \& Asano, T. (2010). Use of treated municipal wastewater in irrigated agriculture-Review of some practices in Spain and Greece. Agricultural Water Management, 97, 1233-1241. https://doi.org/10.1016/j.agwat.2010.03.003

Severino, L. S., Cardoso, G. D., Vale, L. S., \& Santos, J. W. (2005). Método para determinação da área foliar da mamoneira (Embrapa Algodão, Boletim de Pesquisa e Desenvolvimento, 55, p. 20). Embrapa Algodão, 
Campina Grande, Brazil. Retrieved on April 20, 2018, from https://www.infoteca.cnptia.embrapa.br/ bitstream/doc/275969/1/BOLETIM55.pdf

Sousa, E. P. (2015). Qualidade físico-química e microbiológica de água residuária doméstica pós-tratada em fluxo descendente intermitente (90f., Dissertação (Mestrado Profissional em Sistemas Agroindustriais), Universidade Federal de Campina Grande, Pombal).

Souza, Á. H. C., Rezende, R., Lorenzoni, M. Z., Seron, C. C., Hachmann, T. L., \& Lozano, C. S. (2017). Response of eggplant crop fertigated with doses of nitrogen and potassium. Revista Brasileira de Engenharia Agrícola e Ambiental, 21(1), 21-26. https://doi.org/10.1590/1807-1929/agriambi.v21n1p21-26

Tak, H. I., Babalola, O. O., Huyser, M. H., \& Inam, A. (2013). Urban wastewater irrigation and its effect on growth, photosynthesis and yield of chickpea under different doses of potassium. Soil Science and Plant Nutrition, 59, 156-167. https://doi.org/10.1080/00380768.2012.761570

Wang, Y., Jiang, J., Zhao, X., Liu, G., Yang, C., \& Zhan, L. (2006). A novel LEA gene from Tamarix androssowii confers drought tolerance in transgenic tobacco. Plant Science, 171, 655-662. https://oi.org/10.1016/ j.plantsci.2006.06.011

Zubairu, Y., Oladiram, J. A., Osunde, O. A., \& Ismaila, U. (2017). Effect of nitrogen fertilizer and fruit positions on fruit and seed yields of Okro (Abelmoschus esculentus L. Moench). Journal of Plant Studies, 6(1), 39-45. https://doi.org/10.5539/jps.v6n1p39

\section{Copyrights}

Copyright for this article is retained by the author(s), with first publication rights granted to the journal.

This is an open-access article distributed under the terms and conditions of the Creative Commons Attribution license (http://creativecommons.org/licenses/by/4.0/). 